\title{
A Study to Investigate the Impact of the COVID-19 Pandemic on Tourist Arrivals in Belize
}

\author{
Jian Cheng, Zharina Zetina \\ Hebei University of Economics and Business, Shijiazhuang, China \\ Email: zzharina@gmail.com, zzharina@yahoo.com
}

How to cite this paper: Cheng, J., \& Zetina, Z. (2021). A Study to Investigate the Impact of the COVID-19 Pandemic on Tourist Arrivals in Belize. Open Journal of Social Sciences, 9, 326-334. https://doi.org/10.4236/jss.2021.97023

Received: June 1, 2021

Accepted: July 20, 2021

Published: July 23, 2021

Copyright ( 2021 by author(s) and Scientific Research Publishing Inc. This work is licensed under the Creative Commons Attribution International License (CC BY 4.0).

http://creativecommons.org/licenses/by/4.0/

\begin{abstract}
This study examines the impact of the COVID-19 pandemic on tourist arrivals in Belize using secondary quantitative data from 2011-2020. The researcher deployed the use of SPSS 25.0 statistical software and advanced technical skills to generate graphical analysis to reveal the damage caused by the COVID-19 pandemic. The research concludes that the Coronavirus pandemic has been the worst exogenous shock to the tourism industry. Now, policymakers are at a critical standpoint to access the economic damage and seek ways to rebuild the economy. Although there is a current vaccine to end the global pandemic, the recovery and immunization will take a while before the tourism industry can fully return to normalcy. This report highlights the drastic decline in tourist arrivals caused by the COVID-19 pandemic as well as suggesting ways how the tourism industry can rebound from its global crisis.
\end{abstract}

\section{Keywords}

COVID-19 Pandemic, Impact, Tourist Arrivals, Recovery

\section{Introduction}

Belize is a small country within the region of Latin America and the Caribbean with an estimated population of 397,628 people (Worldometer, 2020). The country is bordered by two Spanish-speaking countries, Mexico and Guatemala, and its official language is English. The country's annual gross domestic product (GDP) net worth was recorded at 1.88 billion US dollars (The World Bank, 2019) which is largely based on the tourism service trade sector. Yet, the Inter-American Development Bank (IDB) reported that the growth rate is low (Rivero, Leslie, Ruiz-Arranz, López Ghio, \& Vasquez, 2020). The World Bank, 
(2020) issued a report stating that the COVID-19 pandemic hit at a time when the country was already going through a state of recession due to drought and downturn in tourism during the second half of 2019.

Before, the tourism industry was considered the strongest economic pillar as it accounts for more than $40 \%$ of gross domestic product (GDP) and employed almost $40 \%$ of the total population in Belize (World Travel \& Tourism Council, 2018). In 2020, the country's gross domestic product (GDP) contracted by $16 \%$ (International Monetary Fund, 2020) as a result of the global pandemic. The Organization for Economic Co-operation and Development (OCED) highlighted that the tourism sector was one of the first industries to be deeply affected by the outbreak of the coronavirus (Jane, 2020). Since then, the tourism industry has been struggling to survive with little to no international travelers.

\section{Research Problem and Purpose}

The surge of the COVID-19 pandemic has gruesomely impacted the growth of the tourism service trade sector and the economic development of Belize. The recovery period will be slow as countries slowly reopen their borders and travelers regain trust to safely travel around the world. This study will assess the damage caused by the COVID-19 pandemic by reviewing secondary tourist arrival statistics for the past ten years and give suggestions that can be taken for the recovery of the industry.

\section{Literature Review}

Since the outbreak of the novel coronavirus, numerous scholars have written about the impact of the COVID-19 pandemic on the tourism sector. In March 2020, the World Health Organization (WHO) advised all governments around the world to take extra precautions as they faced the preliminary phase of a health emergency (Moreno-Luna et al., 2021). Thereafter, most countries imposed travel restrictions that halt the movement of international tourists. As a result, it has caused the number of arrivals to almost reach zero in some cases (Mulder, 2020). The United Nations World Trade Organization (UNWTO) (2020a), highlighted that the estimated deterioration of international travelers in 2020 is equivalent to a loss of about 1 billion tourist arrival and US $\$ 1.1$ trillion in international tourism receipts with an economic loss of over US $\$ 2$ trillion in the global gross domestic product (GDP). Also, the UNWTO (2020a) adds that a 70\% decline in international tourism in 2020 reflects the amount of tourism 30 years ago.

This drastic reduction of international travelers has a devastating impact on tourism-dependent countries. Narayanan et al. (2021) argued that the decline in tourist arrivals affected the gross domestic product (GDP), employment, and income along the supply chain. While Vivas Eugui \& Contreras (2020) argued that it disrupted the collection of tax revenues and sources of foreign exchange. The UNWTO (2020) claimed that the tourism industry supports one in every 10 jobs, which acts as the main source of livelihoods for most individuals. Never- 
theless, in 2020, 174 million jobs were under threat if travel restrictions remained (World Travel \& Tourism Council, 2020). Hussain \& Fusté-Forné (2020) emphasize that in the long run if millions of tourism-related jobs are lost, then it can result in a global human socio-economic crisis. Moreover, the collapse of the industry during the pandemic had a domino effect on other industries. Moreno-Luna et al., (2021) pointed out that one job in the tourism sector creates about one-and-a-half additional or indirect jobs such as food and beverage provisions, handicrafts, and the preservation of cultural and natural assets. Likewise, the airlines and cruise ships industry also suffered from the decreased demand of international travelers and had to file for bankruptcy (Narayanan Gopalakrishnan, Peters, \& Vanzetti, 2021).

Still, it is challenging to predict the expected recovery of the tourism industry. According to a survey from the UNWTO Panel Experts on the impact of the COVID-19 on tourism and the expected recovery, it revealed that $80 \%$ of the experts predict a rebound of the tourism industry in the 3rd quarter of 2021, while $20 \%$ of the expert predict that recovery will only be in 2022 (UNWTO, 2020b). However, several factors hinder the resumption of international tourism. The same survey reported that the main barrier disrupting the resumption of international tourism is travel restrictions followed by slow virus containment and low consumer confidence. Besides, the traveling cost is a little high if social distance measures are continually being enforced within the airlines (Narayanan Gopalakrishnan, Peters, \& Vanzetti, 2021).

Belize is among the most affected countries that heavily rely on income generated by the tourism industry. Cafasso (2020) argued that on an annual basis, the rich rainforest and magnificent Mayan ruins experiences generate over USD 15 million in Belize's economy from 13 tourism hotspots and 27 resorts. However, in 2020 , Belize economy contracted by $15.5 \%$ with the inflation rate rising to $0.3 \%$ in September of that year reflecting higher prices for food, health, and housing, as well as the fiscal deficit, expanded from $3.4 \%$ to $11.0 \%$ in the first quarter of 2019 and 2020 respectively (ECLAC, 2020). As a result, the Inter-American Development Bank stated that the global pandemic can shrink the size of the economy to the levels of 2011 (Rivero, Leslie, Ruiz-Arranz, López Ghio, \& Vasquez, 2020). The World Bank (2020) has confirmed that the most affected sector is tourism with $66 \%$ of job losses which can increase the poverty level in Belize. In addition, $80 \%$ of tourism-related jobs were lost due to the pandemic (United Nations Development Programme, 2020).

Abreast of the situation, the Government of Belize implemented several measures aimed at softening the economic damage caused by the pandemic. Firstly, a COVID-19 relief program was implemented that provided 150 Belize dollars (BZ\$) every 2 weeks for unemployed individuals and BZ\$2500 to support micro-, small and medium-sized enterprises (MSMEs) (ECLAC, 2020). Also, Moloney (2020) highlighted that most indigenous people in Belize, like the Garifunas, returned to their traditional roots by raising chicken and growing herbal gardens to sustain their livelihood. Some countries are promoting the use 
of domestic tourism to cushion their economy, but the population of Belize is very small to make up for the loss of international tourists. Moreover, United Nations Conference on Trade and Development (UNCTAD) (2020) argued that the COVID-19 pandemic disrupted the supply chain, halted tax revenue and sources of foreign reserve generated from the productive sector, and briefly depressed demand globally. The lack of adequate foreign exchange prompted the Government of Belize to heighten borrowings and increase its debt load, further compounding the difficulty in charting a recovery. Altogether, the COVID-19 pandemic destructed the economy by affecting the employment, consumption, foreign reserve earnings, tax revenue, and poverty level in Belize.

\section{Methodology}

\subsection{Research Design}

The researcher used a quantitative research method to investigate the impact of the COVID-19 pandemic on tourist arrivals. This type of research design is more suitable since the researcher will need to collect statistical data regarding the number of international travelers entering the country over a period of time. Also, it is more convenient to use secondary data since the research requires the utilization of historical time series data.

\subsection{Data Collection}

To fulfill the objective of this research, the researcher collected tourist arrivals statistics which include both overnight tourist arrivals and cruise ship arrivals. All of the data were collected from the most credential data source such as the Statistical Institute of Belize and the Central Bank of Belize. The researcher collected a total of 20 variables during 10 years from 2011-2020. This period was selected because it represents a time when there was a significant rise in international arrivals to when the country experienced its drastic fall in tourism. Besides, inward arrivals statistics were best suited for the research since the researcher wanted to monitor how the COVID-19 pandemic affected the number of international visitors in Belize.

\subsection{Data Analysis}

After collecting all the data, the researcher manually inputted each variable in SPSS 25.0. To analyze the data, the researcher had to pre-code each variable in SPSS 25.0. This process involves identifying, classifying, and assigning a numeric symbol to each data. Once the data were correctly sorted and organized within the statistical software, then the researcher could efficiently perform a graphical analysis to showcase the drastic decline in tourist arrivals during the COVID-19 pandemic.

\section{Results}

The first chart (Figure 1) showed that overnight tourist arrivals have consistently 


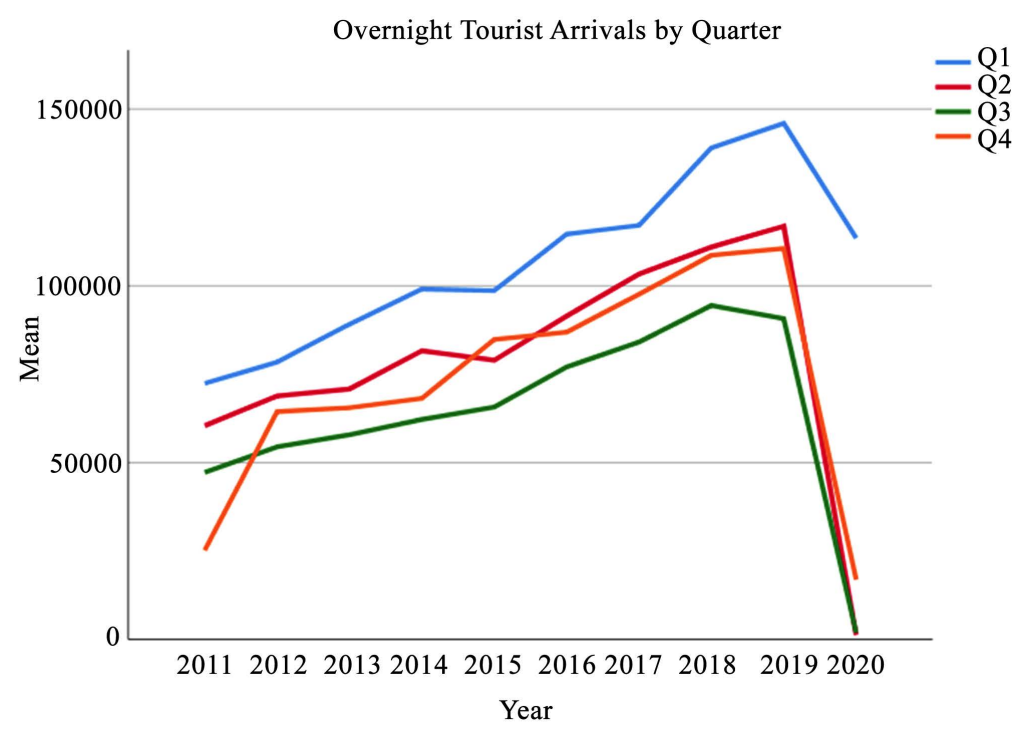

Figure 1. Overnight tourist arrivals. Source: Central Bank of Belize, (2020b); Statistical Institute of Belize (2020).

grown over the years in each of the four quarters. In 2020, the figures drastically drop due to the outbreak of the novel coronavirus. The number of overnight tourist arrivals did not significantly drop within the first financial quarter but was still affected by other interconnected flights and travel restrictions from other countries. The second and third quarters experienced a drastic drop in overnight tourist arrivals when all borders and ports of entry were closed in March 2020. The fourth quarter slightly experienced an increase in overnight tourist arrivals as the airports were once again opened in October 2020. Nevertheless, travel movements remained slow for the remainder of 2020 up until 2021.

The second chart (Figure 2) shows that over the past years cruise tourists accounts for almost double the number of overnight tourist arrivals. It accounts for the largest share of tourist arrivals in Belize. The United Nations reported that many cruise ships had outbreaks of the virus at sea after disembarking from international trips (Mulder, 2020). This resulted in a major collapse of the industry as many countries refused to allow docking facilities. Belize only reported three months of cruise ship arrivals in 2020. Thereafter, all ports were closed. In total, the country suffered a 70.8\% drop in tourist arrivals after the closure of all ports of entry in March 2020. The Central Bank annual report highlighted that the cruise ship industry suffered a historical loss from the COVID-19 pandemic compared to the lowest tally from the 2008 global financial crisis where the total amount of cruise visitors plunge from 537,632 to 308,003 in 2020 (Central Bank of Belize, 2020a). On July 8th, 2021, Belize historically welcomes its first cruise ship, Carnival Vista, with a total of 2,810 passengers on board with over 97 percent vaccination rate after a year of cruise suspension to contain the spread of the novel coronavirus (Bodden, 2021). This shows a positive sign of recovery to the cruise industry since more cruise ships will be returning to the beautiful shores of Belize. 


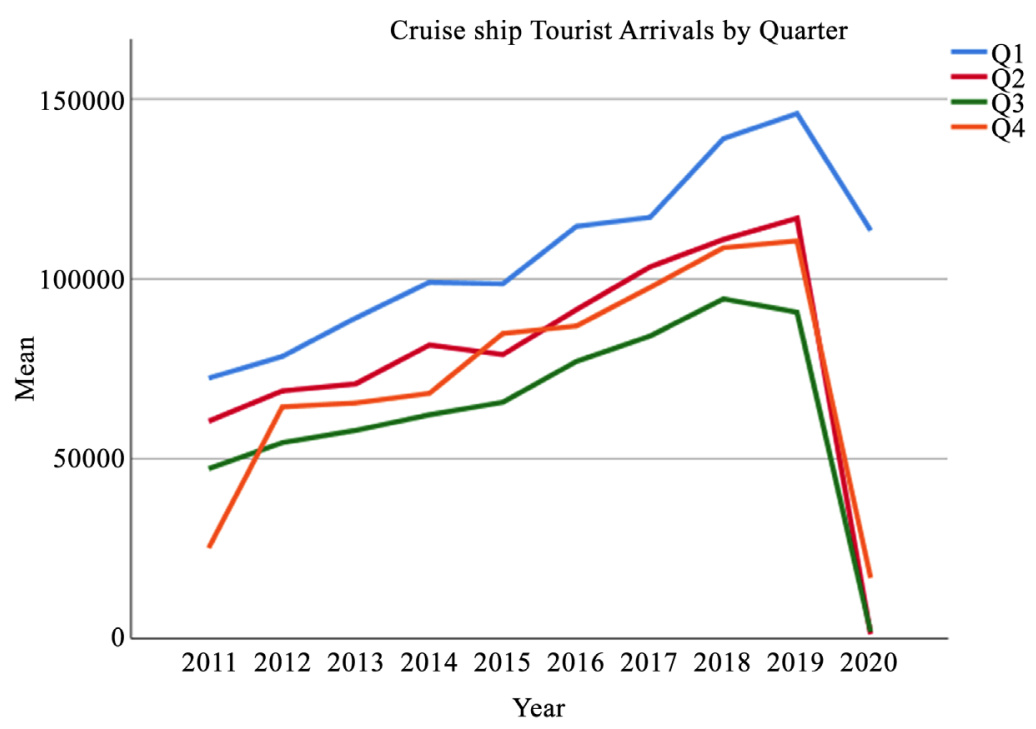

Figure 2. Cruise ship tourist arrivals. Source: Central Bank of Belize (2020b); Statistical Institute of Belize (2020).

\section{Countermeasure for a Safe Reopening of the Tourism Industry}

The tourism industry was the key economic pillar that was hard hit by the novel coronavirus. Yet, it is one industry that has a major capability to rebound stronger from the devastating experience of the global health pandemic. Now, it has caused policymakers to strengthen measures and secure the development of other industries that won't put a severe strain on the economy if one industry should collapse.

The following are countermeasures that can use for the safe resumption of international tourism in Belize.

\subsection{Employ the Use of International Health Standard}

The government of Belize should ensure that adequate health procedures and emergency health plans are put in place for the safe resumption of all modes of international travelers (cruise ships and air passengers). These safety plans should be regularly monitored and updated according to the global standardized health and hygiene guidelines imposed by the World Health Organization (WHO) and the Center for Disease Control and Prevention (CDC) especially since the virus is changing its characteristics. Next, the government should conduct a risk assessment report bi-weekly and monthly to evaluate how efficiently the country's health plan is working and make adjustments where necessary by either loosening or tightening regulations. Likewise, the government should offer international standard safety health training programs to tour operators and tour guides to incorporate within their daily jobs whilst dealing with tourists.

\subsection{Full Cooperation between Private and Public Sector}

The tourism industry is a diverse industry that heavily relies upon other indus- 
tries within the economy. Private and public sectors must collaboratively work together to provide a hygienic safe environment for international tourists. All international tourists visiting the country must stay within golden standard accommodation. Hotel managers should create a hygienic checklist for the daily sanitization of the hotel. Each supervisor should ensure that the daily sanitization is completed by signing at the bottom of the checklist form. The ministry of health along with the ministry of tourism should send health officials to conduct routine spot checks to ensure that adequate health, hygiene, and safety protocols are adhered to. Each golden standard hotel must record and monitor the body temperature of all employees, guests, or persons within the building daily. Likewise, each golden standard hotel or transportation system must keep a detailed logbook of all guests to easily conduct a contact tracing if any susceptible case arises. If possible, tour operators or hotels should make a record of their guest itineraries as part of their health and safety plan to curb any potential spread of the novel coronavirus.

\subsection{Community Participation \& Communication}

It requires a nationwide collaboration and responsibility for the reopening of the tourism industry and other sectors of the economy. All citizens must abide by the law and regulations set in place for the COVID-19 pandemic by wearing a mask, avoid large public gatherings, and adhere to the curfew and social distancing protocols. Likewise, eligible persons must consider taking the vaccine at the nearest public clinic. All citizens must remain calm and should not panic over the resumption of international tourism as the government will do its utmost best to safely reopen all the borders and ports of entry. There should be no rumor or the circulating of false information that will interrupt the trust of other citizens and international travelers. The media outlet, as well as the responsible government agencies, should educate and keep the public well informed to avoid the spread of falsifying information.

\section{Conclusion}

After analyzing the impact of the COVID-19 pandemic on tourist arrivals in Belize, it has shown that the global health crisis has been the worst disaster for the tourism industry. It was certainly not a catastrophe which policymakers were preparing for as they now need to rethink and restructure the economy from tourism being the sole economic pillar. Nevertheless, there is hope that the tourism industry will rebound stronger as ever after learning from its detrimental experience. As Stuart-Hill \& Sutfin (2020) stated that each shock or crisis to the tourism industry is always followed by a period of recovery, then stabilization. The most difficult task during the recovery period is to regain travelers' and business owners' confidence since the vaccine doesn't guarantee a $100 \%$ chance of contracting the virus. The above countermeasures should be taken into deep consideration for the full reopening of the tourism industry. Besides, all parties 
such as travelers, citizens, employees, business owners, and tour operators should play their parts by taking their responsible action to always wear a mask and maintain social distance.

In conclusion, this research contributes to the ongoing literature on how the tourism industry is affected by the global health pandemic. As the virus is still affecting the globe, further research needs to be conducted to examine the full damage caused by the COVID-19 pandemic and whether the vaccine helps to regain traveler's trust in fully reopening the tourism industry.

\section{Conflicts of Interest}

The authors declare that there are no conflicts of interest regarding the publication of this paper.

\section{References}

Bodden, P. (2021, July 8). Belize Welcomes Carnival Vista Cruise. Belize Tourism Board. https://www.belizetourismboard.org/belize-welcomes-carnival-vista-cruise/

Cafasso, S. (2020). Stanford Researchers Help Belize Plan for Sustainable, Nature-Based Development to Create More Economic Resilience amid the Global Pandemic. Stanford News, Stanford Natural Capital Project.

Central Bank of Belize (2020a). 2020 Annual Report \& Statement of Accounts. Belize City, Belize: Central Bank of Belize.

Central Bank of Belize (2020b). Key Tourism Indicators. Belize City, Belize: Central Bank of Belize.

ECLAC (2020). Preliminary Overview of the Economies of Latin America and the Caribbean. United Nations (ECLAC).

Hussain, A., \& Fusté-Forné, F. (2021). Post-Pandemic Recovery: A Case of Domestic Tourism in Akaroa (South Island, New Zealand). World, 2, 127-138.

https://doi.org/10.3390/world2010009

International Monetary Fund (2020). World Economic Outlook: A Long and Difficult Ascent. Washington DC: International Monetary Fund.

Jane, S. (2020). Rebuilding Tourism for the Future: COVID-19 Policy Responses and Recovery. OECD Policy Responses to Coronavirus (COVID-19), OECD Tourism Paper.

Moloney, A. (2020). Caribbean Indigenous People Return to Roots as COVID-19 Shrinks Tourism. Thomson Reuters Foundation, US-Health-Coronavirus-Caribbean-Tourism.

Moreno-Luna, L., Robina-Ramírez, R., Sánchez-Oro Sánchez, M., \& Castro-Serrano, J. (2021). Tourism and Sustainability in Times of COVID-19: The Case of Spain. International Journal of Environmental Research and Public Health, 18, 1859.

https://doi.org/10.3390/ijerph18041859

Mulder, N. (2020). The Impact of the COVID-19 Pandemic on the Tourism Sector in Latin America and the Caribbean and Options for a Sustainable and Resilient Recovery. Santiago: Economic Commission for Latin America and the Caribbean (ECLAC), United Nations.

Narayanan Gopalakrishnan, B., Peters, R., \& Vanzetti, D. (2021). COVID-19 and Tourism: Assessing the Economic Consequences. Geneva: United Nations, UNCTAD.

Rivero, M. M., Leslie, J., Ruiz-Arranz, M., López Ghio, R., \& Vasquez, G. (2020). BIDeconomics Belize: Developing a Sustainable, Resilient \& Inclusive Belize. Felipe Herrera 
Library, Inter-American Development Bank.

Statistical Institute of Belize (2020). Tourism, Statistical Institute of Belize. Belize City, Belize: Statistical Institute of Belize.

Stuart-Hill, T., \& Sutfin, E. (2020). The Recovery Equation: Travel and Tourism in the Post Pandemic Era; the Relationship between 'Industry Transparency' and Speed of Recovery. Hospitality net. https://www.hospitalitynet.org/opinion/4101159.html

The World Bank (2019). The World Bank Data Catalog. The World Bank. https://datacatalog.worldbank.org/dataset/world-development-indicators

The World Bank (2020). Belize-Pubdocs.worldbank.org. https://pubdocs.worldbank.org/en/353311582655270329/mpo-blz.pdf

United Nations Development Programme (2020). Support to the National Response and recovery to Contain the Impact of COVID-19. Belize: Regional Bureau for Latin America and the Caribbean, UNDP.

UNWTO (2020a). Impact Assessment of the Covid-19 Outbreak on International Tourism. UNWTO.

UNWTO (2020b). Tourism And COVID-19-Unprecedented Economic Impacts. World Tourism Organization, Secretary-General's Policy Brief on Tourism and COVID-19.

Vivas Eugui, D., \& Contreras, C. (2020). COVID-19 in the Caribbean and the Central America Region: Identifying Blue Pathways to Move Forward in a COVID-19 Context and Beyond. UNCTAD.

World Travel \& Tourism Council (WTTC) (2018). Travel \& Tourism Economic Impact 2018 Belize. London, UK: World Travel \& Tourism Council.

World Travel \& Tourism Council (WTTC) (2020). 174m Travel \& Tourism Jobs Could Be Lost Due to COVID-19 and Travel Restrictions, Says WTTC. World Travel \& Tourism Council.

Worldometer (2020).

https://www.worldometers.info/world-population/belize-population/ 